\title{
Industrial decline and labor reallocation in a transforming economy: Romania in early transition
}

John S Earle 1,2

\footnotetext{
Correspondence: earle@gmu.edu ${ }^{1}$ School of Public Policy, George Mason University, Arlington, VA, USA

${ }^{2}$ Department of Economics, Central European University, Budapest, Hungary
}

\begin{abstract}
Industrial decline and restructuring in the transition economies presents a prime example of the relationship between changes in aggregate economic indicators and underlying microeconomic adjustments. This paper employs matched labor force survey data to focus on the magnitude and determinants of the labor market flows associated with the fall in industrial employment in Romania from 1993 to 1995. The data show not only a large drop in aggregate industry employment, but also a decline in each of the disaggregated two-digit sectors. Nonetheless, there are substantial gross flows in both directions, again with significant heterogeneity across sectors. Workers leaving jobs in industry have a variety of destinations: jobs in other industrial sectors, in agriculture, and in services, as well as unemployment and non-participation in the labor force; the data show all of these paths to be significant. Multinomial logit estimates indicate that the probability of paths is affected by both individual and firm characteristics. Among other results, university and general high school education tend to raise the probability of job-to-job flows, particularly from industrial jobs to other industrial jobs and to service sectors, but not to agriculture. Workers with primary and vocational education have the highest probability of becoming unemployed and the lowest probability of finding new jobs in services (less than a third the probability for those with university education). Compared with workers in state-owned companies, workers from the private sector, especially from enterprises of mixed ownership have a greater probability of exiting their industry, as well as higher probabilities of finding jobs in services. The largest outflows, however, concern workers from industrial cooperatives, most of whom become unemployed. The data present a mixed picture of social dislocation and improved reallocation.
\end{abstract}

Keywords: Unemployment, Sectoral shifts, Reallocation, Labor force status, Labor force surveys, Romania

JEL codes: J21, J23, J24, J26, J60, J68, O12, P31

\section{Springer}

\section{Introduction}

The strong priority on rapid development of the industrial sector in the centrally planned economies gave rise to a counterpart process in the early transition: deindustrialization. Figure 1 shows the decline in the percentage of total employment accounted for by industry (including both mining and manufacturing) from 1989 to 


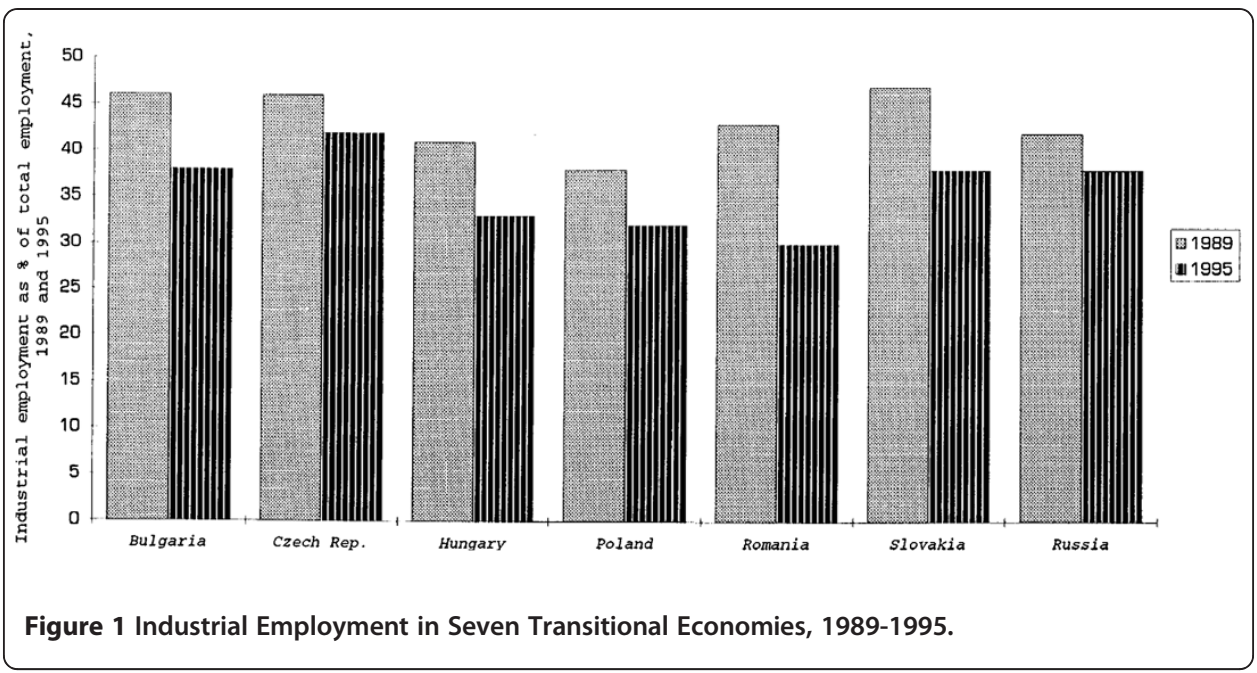

1995 in several East European countries. The drop is large in all cases, but it is by far the largest in Romania.

Although the existence of the decline in industrial employment is well-known (if not the fact of Romania's pre-eminence in at least this dimension of transition), there is little consensus on its meaning. Some observers tend to equate the decline of industry with economic deterioration more generally, and they stress the social costs of job loss in the formerly well-paid industrial sectors. Others emphasize the inherited misallocation of labor and see the decline as a reflection of progress in restructuring.

In this paper, I argue that both views may have some validity, but that an evaluation of the fall in industrial employment depends on a number of factors that have heretofore not been measured. The paper employs a unique data set - matched labor force survey files on 22,161 working age Romanians in 1993 and 1995 - to quantify some of the important factors and to improve understanding of the labor reallocation process associated with the industrial decline. After a brief description of the data and the changing characteristics of industrial employment in section 2, the discussion is organized around three sets of results.

The first set concerns the measurement of the flows of industrial labor in Romania from 1993 to 1995. Information on the change in total industrial employment obscures the possibility that disaggregated industrial sectors have had heterogeneous experiences of decline, with expansion in some areas and decline in others; if such heterogeneity is significant, it would support the view that significant reallocation of labor is occurring. The change in total industrial employment also masks the possibility that there may be significant inflows as well as outflows from industry. The existence of inflows would again support the reallocation view, in the sense that the composition, if not the numbers employed, of labor would be changing. Is there some dynamism in Romanian industry during this early transition period such that there exists significant turnover of employment and such that sub-sectors display some heterogeneity in their labor market behavior, or is the industrial sector characterized by uniform decline? In section 3, I present evidence on these issues. 
The second set of results concerns the employment status in 1995 of workers employed in industry in 1993. In addition to remaining employed in the same industrial sector, five possible destinations for those who change status are distinguished: employment in a different industrial sector, employment in services, employment in agriculture, unemployment, and nonparticipation in the labor force. What is the relative importance of each of these destinations? How one evaluates the overall drop in industrial employment depends at least partially on the answer to this question. If most movers end up in unemployment, in labor force withdrawal, or in marginal agricultural activities, then it would appear that the substantial down-sizing is accompanied by relatively little genuine reallocation occurring, at least during the time period under observation. On the other hand, if most movers have new jobs in other industrial sectors or in services then the observed outflows of employment from industrial sectors is merely one side of the process by which labor is reallocated to new uses. Which view is near to the truth? In section 4, I attempt to answer this question by analyzing 1993-95 employment transition matrices for the entire matched labor survey sample (22,161 observations) as well as on a more detailed basis for those employed in industry $(5,581)$ in 1993.

The final set of issues concerns the impact of individual and firm characteristics on the process of industrial labor reallocation over the 1993 to 1995 period. What types of industrial workers have tended to move, and which characteristics tend to raise the probability of each of the alternative destinations? In addition to examining gender, age, and urban/rural residence, I focus particularly on the effect of different types of education on the probability that an industrial worker in 1993 moves to unemployment, to nonparticipation in the labor force, and to different types of jobs. Does the amount of human capital (measured by schooling) or the specificity of skills (measured by attendance at more general or more specific educational programs) affect the flexibility of worker response and the quality of labor market outcomes? With respect to characteristics of the industrial employer in 1993, I focus on ownership, motivated by the possibility that differences in corporate governance give rise to different labor market behavior. Is private ownership associated with greater or lower outflows of labor and with any differences in the destination of those workers who leave? In section 5, I investigate these questions using a multinomial logit framework.

Section 6 provides some conclusions and suggestions for future research.

\section{Data}

The data set analyzed in this paper is based on labor force surveys (LFS) conducted in March 1994 and March 1995 in Romania. The surveys have almost identical questionnaires requesting standard information on labor force activities, and they permit the first reliable estimations of a number of critically important aspects of the Romanian economy, including the size and characteristics of LFS unemployment and the composition of employment by industry, ownership, and other characteristics (information that was highly biased when based on surveys of enterprises). Unfortunately the surveys contained no questions on earnings or non-labor incomes, nor do they have information on many personal and enterprise characteristics.

For the purposes of this paper it is useful that a substantial proportion of the 1994 sample was re-interviewed in 1995 , and the data sets provide variables sufficient to 
obtain a reliable match between individuals across files. ${ }^{1}$ The matching procedure first matched the codes of the highly disaggregated census collection centers - including the district, the town, and the urban/rural designation - that carried out the surveys. Within each matched center, the code of the dwelling (flat or detached house) was matched, and within the dwelling, the household (for multi-household dwellings) was matched, and the number of the person in the household (which the interviewers had been instructed to keep consistent over the two years). ${ }^{2}$ We then compared the reported gender and year and month of birth across surveys for each matched individual, and excluded all cases in which there were inconsistencies. ${ }^{3}$

Because this paper focuses on the longer run structural changes in labor allocation, I exploit the presence on the 1994 LFS questionnaire of retrospective questions concerning the individual's employment status in the prior year. This retrospective section does not contain the standard ILO questions that would permit the unemployed to be distinguished from nonparticipants, thus the analysis below treats the unemployed and nonparticipants as a single group of "nonemployed" in 1993. ${ }^{4}$ The primary purpose of this paper, however, is to examine the nature of outflows from industrial employment in 1993, an issue for which the retrospective questions are likely to be quite reliable. Moreover, because the 1995 survey contains the ILO questions concerning contemporaneous unemployment, the analysis below is able to distinguish unemployment from nonparticipation as destination states in $1995 .^{5}$

The focus on structural changes in this paper also leads to exclusion of military conscripts and all individuals older than the legal working age (62 for men, 57 for women - beyond which the state pension is available) in 1994 from the sample. I restrict attention to working-age individuals in order to be able to make clearer statements about the issue of the reallocation of labor with strong job attachments, and to avoid confounding the flows with normal retirement and with possible re-entrance of pensioners, a subject deserving a separate analysis.

Table 1 shows the characteristics of the sample. Industrial employees tend to be about the same age, but are more likely to be male and to live in urban areas, relative to the general population. Gender, urban, and age show predictable changes for the general population (none, none, and plus two years, respectively), while these characteristics changed little from 1993 to 1995 for those employed in industry as well.

Types of education receive particular attention in the analysis of the determinants of labor market flows in section 5 below. The categories shown in the table are collapsed from the original questionnaire, and definitions are as follows. "Primary" includes both "primary" and "secondary" (junior high, or middle) school; these are individuals with less than or equal to eight years of schooling. "Vocational" involves 1-2 years of highly specialized training in some craft after 8 years of basic education. "High school" includes 12 years of general education, as well as some specialization in the last years (academic, or at least white collar, although it was the practice to provide many students at academic high schools with training in crafts or machinery operation). "Technical and foreman" training refers to advanced vocational education generally for students who had finished high school, but also for some with only vocational training.

The patterns of education shown in the table reflect the priorities of the Communist economic system. First, there is, by international standards, a very low rate of completion of university and graduate school and a high rate of vocational training and 
Table 1 Characteristics of sample and of industrial employment

\begin{tabular}{|c|c|c|c|c|}
\hline & \multicolumn{2}{|c|}{1993} & \multicolumn{2}{|c|}{1995} \\
\hline & Total & Industry & Total & Industry \\
\hline Age in 1994 (mean years) & 37.6 & 37.4 & 37.6 & 36.2 \\
\hline \multicolumn{5}{|l|}{ (Percent by age group) } \\
\hline$<=25$ & 23.2 & 12.8 & 23.2 & 15.5 \\
\hline $26-35$ & 20.2 & 29.6 & 20.2 & 30.3 \\
\hline $36-45$ & 26.3 & 37.4 & 26.3 & 37.7 \\
\hline $46-55$ & 20.7 & 16.9 & 20.7 & 14.7 \\
\hline$>55$ & 9.7 & 3.2 & 9.7 & 1.8 \\
\hline Gender (percent male) & 50.4 & 58.2 & 50.4 & 59.0 \\
\hline Location (percent urban) & 55.6 & 70.1 & 55.6 & 71.4 \\
\hline \multicolumn{5}{|l|}{ Education (percent by category) } \\
\hline Primary & 43.1 & 24.4 & 42.6 & 23.5 \\
\hline Vocational & 21.3 & 36.7 & 21.7 & 37.9 \\
\hline High School & 22.7 & 25.1 & 22.7 & 25.0 \\
\hline Technical and Foreman & 5.8 & 7.6 & 5.7 & 7.1 \\
\hline University and Graduate & 7.1 & 6.2 & 7.3 & 6.5 \\
\hline Employed (percent) & 68.7 & 100.0 & 71.0 & 100.0 \\
\hline \multicolumn{5}{|c|}{ Ownership of Employer (percent by type) } \\
\hline State & 67.7 & 90.4 & 56.6 & 84.1 \\
\hline Private & 28.8 & 5.2 & 40.1 & 10.7 \\
\hline Mixed & 1.1 & 0.9 & 1.8 & 2.8 \\
\hline Co-operative & 2.4 & 3.5 & 1.5 & 2.4 \\
\hline Sample (no. of respondents) & 22161 & 5581 & 22161 & 4849 \\
\hline
\end{tabular}

primary education. The rate of primary education is much lower among industrial employees, and specialized technical training much higher. Together with the technical and foreman training, vocational training accounts for nearly half the employment in industry. The proportion with university education is slightly lower than in the sample as a whole. The predominance of various types of technical education are a reflection of the widespread programs in vocational education developed by the Ceaucescu regime to fuel the voracious demands of rapid industrial growth. ${ }^{6}$

The table also shows the changing fraction of the population employed, rising from 68.7 to 71.0 percent, and the ownership of the employer, for employed respondents in the matched sample. The composition by ownership shows dramatic change for the whole sample of employed individuals, with a decline in the percentage employed in the state sector from 67.7 to 56.6 percent. State ownership is more predominant in industry, and the reduction in the state employment in industry is rather less than that overall - from 90.4 to 84.1 percent of total industry employment - although it is still meaningful. Cooperatives also show decline, and the mixed (state-private) sector shows some increase, while the private sector is growing strongly.

Finally, the table shows the decline in industrial employment, from 5581 to 4849 individuals, or by 15 percent, in the matched data set. Official data National Commission for Statistics (1996) show a decline of average annual employment in industry of 12 percent from 1992 to 1994, and of 11 percent from 1993 to 1995. Possibly the discrepancy is due 
to the fact that the source for the estimates are different, the official data being based on a survey of enterprises. Moreover, the figures in this paper refer to a reference week in March of each year, rather than to annual averages. In any case, it is the purpose of the paper to analyze what is by either measure and by any standard a very large decline in industrial employment.

\section{Net and gross flows of industrial labor}

The previous section showed that employment in industry fell dramatically, by 15 percent according to the LFS data, from March 1993 to March 1995 in Romania. This section analyzes this change, decomposing it along two dimensions. First, I disaggregate total industry into 13 sectors and examine employment patterns for each of them separately. Secondly, I decompose the changes in employment levels for total industry and for each sector into the gross changes: gross outflows and gross inflows. ${ }^{7}$

The purpose of these analyses is to provide some assessment of the degree of reallocation occurring inside Romanian industry. If we observe, for instance, uniformly declining levels of employment across sectors that are due to labor outflows with essentially no offsetting inflows, this would suggest that the industrial sector is down-sizing, even collapsing, but that little internal restructuring may be occurring; at least it could not be observed in these data. On the other hand, if there is significant heterogeneity among sectors (particularly if some are actually growing despite the overall decline) and if there are significant inflows of labor (as well as outflows), then this might be taken as evidence of significant restructuring within industry itself. Of course, other types of restructuring (adoptions of new technologies, retraining of workers, changing products, improving quality, establishing more effective incentive pay, etc.) may be occurring, but they are not observable with this data set.

Table 2 shows the changes in the composition of industrial employment together with the gross flows that account for it in total industry, and in 13 disaggregated sectors. The decline in employment, "net outflows" in the table, equals "gross outflows" minus "gross inflows;" all are shown as a percentage of employment (in each industry, respectively) in 1993. The results show a decline in every sector, although the magnitudes are not uniform. The decline ranges from a low of 1.6 percent of $1993 \mathrm{em}$ ployment in mining and utilities (sectors dominated by regii autonome, the legal form for state enterprises remaining indefinitely in state hands and frequently receiving various types of state subsidies) to a high of 25.9 percent in electrical equipment, and close to 20 percent in wood and paper, chemicals and plastics, glass and ceramics, and machine building. The standard deviation in net outflows is 6.9 across sectors, suggesting that there is some degree of heterogeneity in the extent of decline.

The table also shows that gross inflows are quite substantial in the aggregate 21.0 percent - as well as in every sector. They range from a low of 16.1 percent in textiles to a high of 36.8 in metal forming, with an across-industry standard deviation of 6.2. Clearly, some significant hiring is going on, suggesting more dynamism than reflected by the large net outflows. The arithmetic implies correspondingly large gross outflows, which range from 18 percent in mining to 44 
Table 2 The changing composition and the gross flows of industrial employment

\begin{tabular}{|c|c|c|c|c|c|c|}
\hline \multirow[t]{2}{*}{ Industrial Sector } & 1993 & $\begin{array}{c}\text { Gross } \\
\text { Outflows } \\
\end{array}$ & $\begin{array}{c}\text { Gross } \\
\text { Inflows }^{2} \\
\end{array}$ & $\begin{array}{c}\text { Gross } \\
\text { Turnover }^{3} \\
\end{array}$ & $\begin{array}{c}\text { Net } \\
\text { Outflows } \\
\end{array}$ & \multirow{2}{*}{$\begin{array}{c}1995 \\
\text { (\% of total) }\end{array}$} \\
\hline & (\% of total) & \multicolumn{4}{|c|}{ (\% of employed in that industrial sector in 1993) } & \\
\hline Mining & 7.9 & 18.0 & 16.4 & 34.3 & 1.6 & 8.9 \\
\hline Utilities & 5.5 & 27.2 & 25.6 & 52.8 & 1.6 & 6.3 \\
\hline Food \& Tobacco & 8.2 & 31.8 & 24.2 & 56.0 & 7.6 & 8.7 \\
\hline Textiles, Clothing and Leather & 19.9 & 31.9 & 16.1 & 48.0 & 15.9 & 19.2 \\
\hline Wood \& Paper & 6.5 & 43.1 & 25.5 & 68.7 & 17.6 & 6.2 \\
\hline $\begin{array}{l}\text { Refining, Chemicals, Rubber, } \\
\text { Plastics }\end{array}$ & 6.8 & 34.4 & 16.9 & 51.3 & 17.5 & 6.4 \\
\hline Glass \& Ceramics & 4.0 & 35.4 & 16.6 & 52.0 & 18.8 & 3.7 \\
\hline Metallurgy & 6.1 & 34.9 & 25.7 & 60.7 & 9.2 & 6.3 \\
\hline Metal forming & 6.5 & 44.0 & 36.8 & 80.8 & 7.1 & 7.0 \\
\hline Machine building & 14.3 & 37.1 & 17.6 & 54.8 & 19.5 & 13.3 \\
\hline Electrical equipment & 4.7 & 42.6 & 16.7 & 59.3 & 25.9 & 4.0 \\
\hline Transport equipment & 5.6 & 36.7 & 23.8 & 60.5 & 12.9 & 5.6 \\
\hline Furniture and other & 4.0 & 33.5 & 26.3 & 59.8 & 7.1 & 4.3 \\
\hline Total \% & 100.0 & 34.1 & 21.0 & 55.2 & 13.1 & 100.0 \\
\hline Total number & 5581 & 1905 & 1173 & 3078 & 732.0 & 4849.0 \\
\hline $\begin{array}{l}\text { Standard deviation } \\
\text { (across industries) }\end{array}$ & & 7.0 & 6.2 & 11.3 & 6.95 & \\
\hline Correlation between gross outf & NS and gre & nflows $=$ & & & & \\
\hline
\end{tabular}

${ }^{1}$ Gross outflows = number of workers employed in an industrial sector in 1993 and no longer employed in that sector in 1995.

${ }^{2}$ Gross inflows = number of workers employed in an industrial sector in 1995 who were not employed in that sector in 1993.

${ }^{3}$ Gross turnover $=$ gross outflows plus gross inflows.

percent in metal forming, with an aggregate figure of 34.1 and a standard deviation across sectors of 7.0.

An indicator of overall labor market restructuring or "churning" is gross labor turnover, the sum of gross outflows plus gross inflows as a percentage of employment in each industry in 1993. The range for turnover is even wider, varying from 34.3 in mining, which is quite low for a two-year period, to 80.8 percent in metal forming, which is large by international standards. Nearly all sectors have turnover above 50 percent. Moreover, the outflow and inflow rates are positively correlated: across the 13 sectors, the simple correlation coefficient is 0.37 . This suggests, to some considerable degree, that outflows reflect restructuring - the replacement of existing employees with new ones - rather than simple down-sizing, which would have implied a negative correlation.

To summarize, despite the fact that both Romanian industry as a whole and each disaggregated industrial sector have seen significant declines in employment, the data appear to reflect some dynamism and not a mere collapse. We have seen that there is significant heterogeneity across sectors in the size of the decline, and moreover that every sector has positive inflows, as well as outflows. For some sectors, the magnitude of turnover is quite large, suggesting that the sectors may have changed quite a bit, even if the net decline was not as large as in some others. The rather strong positive correlation of outflows and inflows, however, indicates that the decline may be tending 
to reflect dynamism rather than stagnation, in that sectors with more outflows are also likely to be hiring more new workers.

\section{Employment transitions: destinations of industrial labor outflows}

The previous section found some evidence of active restructuring of the industrial sector. In this section, I investigate what has happened to the workers who have left industry over the 1993-95 period. At the risk of some oversimplification, two possible broad categories of outcome can be distinguished.

The first possibility is that the workers who have left an industrial sector have been marginalized by the rapid changes around them. They may have ended up jobless, either unemployed or even withdrawn from the labor force. Given that the analysis in this paper is restricted to working age individuals, the outcome of labor force withdrawal seems particularly negative. Even if the workers have found new jobs, it may be that they have joined the ranks of the subsistence farmers who now account for a large fraction of Romanian employment. ${ }^{8}$ If the data shows that unemployment, labor force withdrawal, and subsistence farming are the predominant destinations for workers leaving industry, then I would argue that the down-sizing of industry has not been successful in releasing labor to other uses. The outflows would be associated not with reallocation, but with a decline in total employment (ceteris paribus) and with a de-modernization of the Romanian economy.

On the other hand, if the workers who have left an industrial sector have found employment in another industrial sector or in services, we may take this as some evidence that the reallocation process has been relatively successful. In this case, the decline of industrial employment would be just one side of the process whereby workers move from less- to more-highly valued uses of their time. Of course, we cannot measure most of the relevant characteristics of the new jobs that might permit us to make stronger statements about the quality of the new compared with the old job. If possible, it would be desirable to compare incomes, fringe benefits, and other work conditions. But some inferences can be drawn nevertheless. The general tendency for socialist economies in general, as well as the Romanian economy in particular, to exhibit misallocation of labor in the sense of over-employment in industry, under-employment in services, and more generally across narrower sectors, is well-known. If we observe workers moving from industry to services, or even to other industrial jobs, then this would appear to be far superior, on average, to the outcomes of unemployment, nonparticipation in the labor force, and subsistence agriculture.

Table 3 provides the beginning of an answer to the nature of sectoral mobility in Romania. The table shows a transition matrix for four states - nonemployment (including both unemployment and nonparticipation, which, as I noted, cannot be properly distinguished in the 1993 data), employment in agriculture, employment in agriculture, and employment in services. ${ }^{9}$ The elements in the matrix are conditional probabilities of the individual being in each state in 1995 - conditional on being in a particular state in 1993. In other words, they are the empirical hazards for the sample.

The data show significant inertia in all four states, reflected in the largest probabilities along the main diagonal, but it is notable that the conditional probabilities of movement from industry to agriculture and to services are both about twice the magnitude 
Table 3 Employment transitions in Romania, 1993 to 1995

\begin{tabular}{|c|c|c|c|c|c|c|}
\hline & Empl & loyment statc & us in 1995 & & & \\
\hline & (in \% of & total in that $g$ & group in 19 & 993) & $\begin{array}{r}1993 \mathrm{En} \\
\text { Com }\end{array}$ & $\begin{array}{l}\text { loyment } \\
\text { sition }\end{array}$ \\
\hline & Nonemployed & Agriculture & Industry & Services & Percent & Number \\
\hline Employment st & & & & & & \\
\hline Nonemployed & 68.7 & 17.8 & 4.6 & 8.8 & 31.1 & 6887 \\
\hline Agriculture & 11.0 & 82.1 & 2.4 & 4.5 & 19.3 & 4278 \\
\hline Industry & 12.0 & 5.4 & 74.8 & 7.8 & 25.2 & 5581 \\
\hline Services & 9.5 & 4.6 & 4.6 & 81.3 & 24.4 & 5415 \\
\hline 1995 Employm & & & & & & \\
\hline Percent & 28.8 & 23.9 & 21.9 & 25.4 & 100 & - \\
\hline Number & 6387 & 5288 & 4849 & 5637 & - & 22161 \\
\hline
\end{tabular}

of the reverse probabilities, and that from industry to nonemployed is nearly three times that of the reverse movement. At the same time and consistent with the earlier finding of significant gross inflows into industry, the data show that nontrivial numbers of workers have entered industry, and from all three of the other destinations. The total outflow from industry is 25.2 percent of industry employment in 1993, which is smaller than the outflow shown in Table 2 because of the different definitions of outflow (outflow from all industry compared to outflow from individual industrial sectors), the difference representing movement within industry.

The table also shows the changing composition of the Romanian population by employment. Nonemployment fell from 31.1 to 28.8 percent and industrial employment fell from 25.2 to 21.9 percent, while agricultural employment rose from 19.3 to 23.9 percent and services rose relatively slightly, from 24.4 to 25.4 percent of the population. The shares in total employment of the three sectors in 1995 were 34 percent (agriculture), 31 percent (industry), and 36 percent (services). Even if the service sector has grown significantly from 1989 (when it was about 28 percent), Romania's economy is still much more dominated by agriculture, and to a lesser degree industry, than most developed economies. $^{10}$

Table 4 focuses on the 1995 destination of individuals employed in industry in 1993. In the aggregate, 65.9 percent remain with the same industrial sector, implying that 34.1 percent have changed status over the two years. Among those who have changed, all destinations are significant: in order of declining importance the 1995 states are other industry, services, nonparticipation, agriculture, and unemployed. But the differences between the incidences of the various states are not large, suggesting an almost exactly equal division between relatively good outcomes in services and other industrial sectors (16.8 percent) and relatively poor ones in agriculture, unemployment, and nonparticipation (17.5 percent). ${ }^{11}$

The table also shows the results of similar calculations for disaggregated industries. Consistent with the findings reported above, the sectors display considerable heterogeneity, with the greatest inertia in mining, and the least in wood and paper, metal forming, and electrical equipment. There is also wide variation in the probability of finding jobs in other industries or services, or in ending up in a worse outcome of agriculture, unemployment, and nonparticipation. For instance, although wood and 
Table 4 Destination of industrial employees in Romania, 1993 to 1995

\begin{tabular}{|c|c|c|c|c|c|c|c|}
\hline \multirow{3}{*}{$\begin{array}{l}\text { Employed in industry in } 1993 \\
\text { By industrial sector }\end{array}$} & \multicolumn{7}{|c|}{ Employment status in 1995} \\
\hline & \multicolumn{6}{|c|}{ (in \% of total in that industrial sector in 1993) } & \multirow{2}{*}{$\begin{array}{c}\text { Total } \\
\text { number } \\
\text { in } \\
\text { sample }\end{array}$} \\
\hline & $\begin{array}{l}\text { Same } \\
\text { Sector }\end{array}$ & $\begin{array}{l}\text { Other } \\
\text { Sector }\end{array}$ & Services & Agriculture & Unemployed & $\begin{array}{l}\text { Out of } \\
\text { Labor } \\
\text { Force }\end{array}$ & \\
\hline Mining & 82.0 & 3.0 & 3.6 & 3.9 & 2.3 & 5.2 & 440 \\
\hline Utilities & 72.8 & 8.4 & 8.7 & 4.2 & 1.9 & 3.9 & 309 \\
\hline Food \& Tobacco & 68.2 & 2.0 & 7.6 & 8.3 & 5.2 & 8.7 & 459 \\
\hline Textile, Clothing, and Leather & 68.1 & 3.6 & 5.0 & 6.0 & 8.3 & 9.1 & 1108 \\
\hline Wood \& Paper & 56.9 & 8.8 & 8.8 & 12.1 & 4.4 & 9.1 & 364 \\
\hline $\begin{array}{l}\text { Refining, Chemicals, Rubber, } \\
\text { Plastics }\end{array}$ & 65.6 & 9.5 & 8.2 & 6.1 & 5.3 & 5.3 & 378 \\
\hline Glass \& Ceramics & 64.6 & 8.1 & 9.0 & 8.5 & 3.6 & 6.3 & 223 \\
\hline Metallurgy & 65.1 & 13.9 & 4.4 & 2.4 & 6.8 & 7.4 & 338 \\
\hline Metal forming & 56.0 & 16.5 & 10.2 & 5.2 & 5.2 & 6.9 & 364 \\
\hline Machine building & 62.9 & 15.1 & 9.9 & 2.1 & 4.0 & 6.0 & 800 \\
\hline Electrical equipment & 57.4 & 14.1 & 13.3 & 3.4 & 5.3 & 6.5 & 263 \\
\hline Transport equipment & 63.3 & 13.2 & 13.5 & 3.9 & 2.9 & 3.2 & 311 \\
\hline Furniture and other & 66.5 & 9.4 & 4.5 & 6.3 & 6.7 & 6.7 & 224 \\
\hline Total & 65.9 & 9.0 & 7.8 & 5.4 & 5.2 & 6.9 & 100 \\
\hline Total number & 3676 & 501 & 434 & 299 & 288 & 383 & 5581 \\
\hline
\end{tabular}

paper, metal forming, and electrical equipment are characterized by nearly the same exit rate - about 43 to 44 percent - they have very different outcomes, with only 17.5 percentage points of the outflow from wood and paper but 27 percent of those from metal forming and electrical equipment finding jobs in other industries and services.

The data demonstrate, therefore, another perspective on the often noted divergence in outcomes between "winners" and "losers" in the transition. Although they do not permit measurement of the income changes associated with these mobility changes, I have argued that some inferences can be drawn from the activity itself. Roughly speaking, the workers who leave an industrial sector find themselves with relatively good outcomes about half the time, relatively bad ones the other half. However, there appears to be significant heterogeneity in the pattern of outcomes, varying with the industrial sector in which the worker was employed in 1993. The next section investigates whether the heterogeneity is associated with different human capital characteristics, different local labor market opportunities, and different ownership of the 1993 employer.

\section{Determinants of the employment transitions of industrial labor}

This section examines possible explanations for the heterogeneity in outcomes. What characteristics of individuals make them more likely to keep their jobs in industry, which increase the probability they will move successfully to a new job in another sector, and which tend to be associated with nonemployment and agriculture? In this section, I investigate this question using a multinomial logit framework. I also examine the impact of the ownership of the worker's employer in 1993 on the probability of the alternative transitions. 
The equation to be estimated is as follows:

$$
P\left(Y_{i}=j \mid X_{i} ; Z_{i}\right)=\frac{e^{X_{i}^{\prime} \beta_{j}+Z_{i}^{\prime} \gamma_{j}}}{\sum_{k=0}^{5} e^{X_{i}^{\prime} \beta_{k}+Z_{k}^{\prime} \gamma_{k}}}
$$

where $Y_{j}=$ the state observed in 1995 , with $j$ varying from 0 to $5 ; \mathrm{X}$ and $\mathrm{Z}$ are vectors of independent variables varying across individuals, who are indexed by $i$; and $\beta$ and $\gamma$ are sets of parameters to be estimated. ${ }^{12}$

$\mathrm{X}$ and Z contain the potential determinants of employment status in 1995. My hypotheses about them are as follows. First, age is likely to raise the probability of staying in the same industry, but among movers to lessen the chance of successful mobility. If the oldest age group (56 to 57 for women, 56 to 62 for men) has a high probability to exit the labor force, then it would appear that the industrial decline is associated with early retirement. Age is measured in several intervals to permit a nonlinear relationship and to assess the behavior of different age groups.

Next, gender is somewhat difficult to predict. If women tend to be laid off before men, then they may have higher outflow probabilities. If they face discrimination in hiring, they may have lower probabilities of finding jobs in other industrial sectors and in services, and more likely be found in agriculture. If their labor supply was partly compelled by the laws against "parasitism" under the Ceaucescu regime, they may be more likely to leave the labor force.

Regarding location, it is difficult to see why the probability of an employer-initiated separation industry would be greater for workers in urban or rural areas, but the probability of an employee-initiated one would likely depend on the prospects on the local labor market. Opportunities would seem to be better for workers in urban areas, where jobs in services and other industries might be available. In rural areas, the industry is likely to be in a one-company or one-industry town, and the only other option would probably be employment in agriculture.

Concerning educational attainment, I would put forward two hypotheses. First, higher levels of schooling would make the individual more employable in new jobs, although also less likely to be laid off from the existing one. Thus, the probability of staying in the same industry may not differ, but the probability of finding a new, desirable job in other industries or in services is likely to be greater for those with more education. Secondly, an argument can be made concerning not the level but the type of education. Individuals with a more general educational background, by contrast with those whose training was highly specific to some occupation or industry, are more likely to have better opportunities in new jobs. Therefore, those who have attended only primary or high school, but not a vocational program, and those who have attended university are more likely to exit their industry, and to find new jobs in services or other industries. For this purpose, I interpret general types of schooling to include primary, high school, and university and graduate education, while the specific types are vocational and technical and foreman training.

The final set of variables concerns ownership of the worker's employer in 1993. The hypotheses here depend on one's view of the private sector. On the one hand, if a respondent's report of employment with a "private" company represents de novo private 
firms, then there may be relatively few outflows because such firms are likely to be growing. On the other hand, if "private" denotes privatized firms, which probably require labor shedding, then the outflow may be greater than from either state or cooperatives. If "mixed" represents partially privatized companies, then the downsizing may be greater there than in state companies, at least if the private owners are able to exercise some control. ${ }^{13}$

The estimation results are presented in Table 5, with the omitted category of the dependent variable designated as those who remain in the same industrial sector. The omitted categories for the independent variables are self-explanatory (or can be inferred by a comparison with Table 1). All of the independent variables appear to matter, in the sense that they are highly significant in at least a few of the comparisons.

The coefficient estimates, of course, provide no information concerning the magnitude of the effects. For this purpose, I have computed the mean predicted probabilities of each 1995 employment status associated with alternative values for the categorical independent variables. For example, where $\mathrm{Z}$ is a dummy variable, the

Table 5 Estimated results from multinominal logit model for gross labor flows, 1993 to 1995

\begin{tabular}{|c|c|c|c|c|c|c|c|c|c|c|}
\hline \multicolumn{11}{|c|}{ Employment status in 1995} \\
\hline & \multicolumn{2}{|c|}{ Other Industry } & \multicolumn{2}{|c|}{ Services } & \multicolumn{2}{|c|}{ Agriculture } & \multicolumn{2}{|c|}{ Unemployed } & \multicolumn{2}{|c|}{$\begin{array}{l}\text { Out of Labor } \\
\text { Force }\end{array}$} \\
\hline & Coeff. & S.E. & Coeff. & S.E. & Coeff. & S.E. & Coeff. & S.E. & Coeff. & S.E. \\
\hline Constant & -3.11 & $0.39^{* * *}$ & -3.88 & $0.47^{* * *}$ & 0.68 & $0.28^{* *}$ & -2.77 & $0.61^{* * *}$ & 0.92 & $0.23^{* * *}$ \\
\hline \multicolumn{11}{|l|}{ Age in 1994} \\
\hline$<=25$ & 0.22 & 0.39 & 0.90 & $0.46^{* *}$ & -1.40 & $0.30^{* * *}$ & 0.80 & 0.62 & -2.44 & $0.26^{* * *}$ \\
\hline $26-35$ & 0.14 & 0.37 & 0.53 & 0.45 & -1.52 & $0.28^{* * *}$ & 0.47 & 0.61 & -3.09 & $0.24^{* * *}$ \\
\hline $36-45$ & 0.25 & 0.37 & 0.47 & 0.44 & -1.65 & $0.28^{* * *}$ & 0.24 & 0.60 & -2.94 & $0.22^{* * *}$ \\
\hline $46-55$ & 0.38 & 0.38 & 0.67 & 0.45 & -0.99 & $0.28^{* * *}$ & 0.12 & 0.62 & -1.65 & $0.21^{* * *}$ \\
\hline Gender (male) & 0.83 & $0.11^{* * *}$ & 0.66 & $0.12^{* * *}$ & -0.44 & $0.14^{* * *}$ & -0.22 & $0.13^{*}$ & -0.81 & $0.13^{* * *}$ \\
\hline Location (urban) & 0.23 & $0.12^{* *}$ & 0.42 & $0.13^{* * *}$ & -2.69 & $0.18^{* * *}$ & 0.41 & $0.15^{* * *}$ & 0.02 & 0.13 \\
\hline \multicolumn{11}{|l|}{ Education } \\
\hline Vocational & 0.18 & 0.14 & 0.17 & 0.16 & -0.76 & $0.16^{* * *}$ & -0.48 & $0.16^{* * *}$ & -0.53 & $0.14^{* * *}$ \\
\hline High School & 0.18 & 0.16 & 0.53 & $0.17^{* * *}$ & -0.96 & $0.21^{* * *}$ & -0.43 & $0.17^{* * *}$ & -0.79 & $0.18^{* * *}$ \\
\hline $\begin{array}{l}\text { Technical and } \\
\text { Foreman }\end{array}$ & 0.02 & 0.21 & 0.60 & $0.22^{* * *}$ & -0.44 & 0.33 & -1.53 & $0.43^{* * *}$ & -0.41 & $0.22^{*}$ \\
\hline $\begin{array}{l}\text { University and } \\
\text { Graduate }\end{array}$ & 0.50 & $0.20^{* * *}$ & 1.13 & $0.20^{* * *}$ & -0.64 & 0.49 & -1.60 & $0.47^{* * *}$ & -1.34 & $0.35^{* * *}$ \\
\hline \multicolumn{11}{|c|}{ Ownership of Employer } \\
\hline Private & -0.23 & 0.26 & 0.73 & $0.19^{* * *}$ & -0.28 & 0.26 & -0.45 & 0.35 & -0.06 & 0.25 \\
\hline Mixed & 0.93 & $0.39^{* *}$ & 0.94 & $0.43^{* *}$ & -0.19 & 0.77 & -0.91 & 1.02 & -0.41 & 0.75 \\
\hline \multirow[t]{2}{*}{ Co-operative } & -0.10 & 0.36 & 0.34 & 0.33 & 0.65 & $0.29 * *$ & 1.40 & $0.22^{* * *}$ & 0.79 & $0.24^{* * *}$ \\
\hline & $\#$ & $\%$ & $\#$ & $\%$ & $\#$ & $\%$ & $\#$ & $\%$ & $\#$ & $\%$ \\
\hline Cases & 501 & 8.98 & 434 & 7.78 & 299 & 5.36 & 288 & 5.16 & 383 & 6.86 \\
\hline \multicolumn{11}{|c|}{ Total \# of observations $=5581$} \\
\hline
\end{tabular}

Sample: all industrial employment in $1993{ }^{* * *} 0.01$ significance level ${ }^{* *} 0.05$ significance level ${ }^{*} 0.10$ significance level. 
predicted probability that $Y_{i}=j$ conditional upon $Z_{i}=0$ and all the other $X_{i}$ is defined as follows:

$$
P_{i j 0}=P\left(Y_{i}=j \mid X_{i} ; Z_{i}=0\right)=\frac{e^{X^{\prime}{ }_{i} \beta_{j}}}{\sum_{k=0}^{5} e^{X^{\prime} \beta_{k}}}
$$

and the predicted probability that $Y_{i}=j$ conditional upon $Z_{i}=1$ and all the other $X_{i}$ is

$$
P_{i j 1}=P\left(Y_{i}=j \mid X_{i} ; Z_{i}=1\right)=\frac{e^{X_{i}^{\prime} \beta_{j}+\gamma_{j}}}{\sum_{k=0}^{5} e^{X^{\prime} \beta_{i}+\gamma_{k}}}
$$

Taking the mean across the 1993 sample of industrial workers of each of these yields $P_{j 0}$ and $P_{j 1}$ :

$$
p_{j 0}=\frac{1}{5581} \sum_{i=1}^{5581} p_{i j 0}
$$

and

$$
p_{j 1}=\frac{1}{5581} \sum_{i=1}^{5581} p_{i j 1}
$$

This method of computing the magnitudes of the effects implied by the nonlinear estimation assumes that the other independent variables (the $\mathrm{X}$ vector) take on their true values for each individual. I simulate changing the value of some dummy variables for the whole sample, allowing all other characteristics to take their true values. The results of the computations are shown in Table 6.

Age has a large effect, although nonmonotonic, on the probabilities. The probability of staying in the same industry is highest for "prime-age" individuals between 26 and 45 years old, and least for those over 55 . The probability of a relatively "good" transition to another industrial sector or to services is lowest for those in the oldest group, well under half the probability for any of the others. Although they have the lowest probability of becoming unemployed, the over-55 group has a higher probability of exiting the labor force than they do of staying in the same sector - just over 40 percent. They are also fairly likely to find jobs in agriculture. Individuals under 45 have relatively low propensities to move to agriculture or to exit the labor force (although the latter is ather higher for the youngest group, possibly reflecting a return to full-time schooling), but they have higher probabilities of becoming unemployed, which indeed is the only probability that declines uniformly with age.

The results concerning gender suggest that women are slightly more likely to retain jobs in the same industry. Among those who leave, however, men are about twice as likely to move to jobs in other industrial sectors or services, while women are more likely to exit to agriculture, to unemployment, and especially to nonparticipation in the labor force.

The urban/rural distinction shows a greater probability of retaining a job in the same industrial sector in urban areas. But there is a higher probability for workers in urban 
Table 6 Predicted probabilities of gross outflows of labor from industry, 1993 to 1995

\begin{tabular}{|c|c|c|c|c|c|c|}
\hline & \multicolumn{6}{|c|}{ Employment status in 1995} \\
\hline & $\begin{array}{l}\text { Same } \\
\text { Sector }\end{array}$ & $\begin{array}{l}\text { Other } \\
\text { Sector }\end{array}$ & Services & Agriculture & Unemployed & $\begin{array}{l}\text { Out of Labor } \\
\text { Force }\end{array}$ \\
\hline \multicolumn{7}{|l|}{ Age } \\
\hline$<=25$ & 0.626 & 0.085 & 0.103 & 0.049 & 0.074 & 0.063 \\
\hline $26-35$ & 0.692 & 0.086 & 0.078 & 0.048 & 0.060 & 0.037 \\
\hline $36-45$ & 0.696 & 0.096 & 0.074 & 0.043 & 0.048 & 0.043 \\
\hline $46-55$ & 0.595 & 0.095 & 0.079 & 0.066 & 0.036 & 0.129 \\
\hline$>55$ & 0.400 & 0.047 & 0.030 & 0.102 & 0.020 & 0.401 \\
\hline \multicolumn{7}{|l|}{ Gender } \\
\hline Male & 0.647 & 0.116 & 0.096 & 0.047 & 0.046 & 0.048 \\
\hline Female & 0.670 & 0.053 & 0.053 & 0.066 & 0.058 & 0.100 \\
\hline \multicolumn{7}{|l|}{ Location } \\
\hline Urban & 0.672 & 0.097 & 0.087 & 0.011 & 0.059 & 0.073 \\
\hline Rural & 0.630 & 0.074 & 0.055 & 0.144 & 0.036 & 0.062 \\
\hline \multicolumn{7}{|l|}{ Education } \\
\hline Primary & 0.630 & 0.074 & 0.052 & 0.076 & 0.074 & 0.095 \\
\hline Vocational & 0.683 & 0.095 & 0.066 & 0.042 & 0.050 & 0.064 \\
\hline High School & 0.677 & 0.094 & 0.093 & 0.035 & 0.052 & 0.050 \\
\hline $\begin{array}{l}\text { Technical and } \\
\text { Foreman }\end{array}$ & 0.676 & 0.080 & 0.100 & 0.056 & 0.018 & 0.071 \\
\hline $\begin{array}{l}\text { University and } \\
\text { Graduate }\end{array}$ & 0.636 & 0.119 & 0.157 & 0.045 & 0.016 & 0.028 \\
\hline \multicolumn{7}{|c|}{ Ownership of Employer } \\
\hline State & 0.666 & 0.091 & 0.074 & 0.054 & 0.049 & 0.067 \\
\hline Private & 0.649 & 0.070 & 0.145 & 0.042 & 0.031 & 0.064 \\
\hline Mixed & 0.563 & 0.187 & 0.151 & 0.042 & 0.017 & 0.041 \\
\hline Co-operative & 0.520 & 0.065 & 0.083 & 0.074 & 0.151 & 0.107 \\
\hline
\end{tabular}

areas to find jobs in services and in other industries (probably since urban areas have more diversified employment opportunities) but lower probability to find employment in agriculture, which is 14 times higher for workers in rural areas.

Concerning education, the differences among types in the probability of leaving the industry sector is small, but there is a pronounced advantage to more schooling in finding employment in other industries, and particularly in services. Individuals with a general high school education do better than those with vocational training at finding jobs in the service sector, and the former are less likely than the latter to end up in agriculture or out of the labor force. University and graduate education are strongly associated with better outcomes, although a large proportion even of this group - 4.5 percent - is predicted to end up in agriculture.

Finally, the ownership of the employer in 1993 appears to matter considerably for employment status in 1995. First, private employers have only marginally higher outflows compared to state employers, consistent with the notion that the private sector is growing, therefore less likely to lay workers off and more likely to offer attractive wages. Mixed employers have significantly larger outflows, consistent with the hypothesis that they represent old firms in need of restructuring, and that the private owners 
have managed to exercise some influence over company behavior. But by far the largest outflows are from the industrial cooperatives, which seem to have essentially collapsed in this period. The probability that a cooperative worker in 1993 would be unemployed or out of the labor force in 1995 is estimated at nearly 26 percent. Workers from the private and mixed sectors are much more likely to find jobs in other industries and in services, and are less likely than state employees to become unemployed.

\section{Conclusion}

The dramatic decline of industry in the transitional economies of Eastern Europe has played a rather ambiguous role in the economics of transition. On the one hand, many economists have tended to bemoan the enormous decline in measured aggregate output as an unexpected calamity inconsistent with basic price theory, and to acclaim the recent upturn in official growth - largely due to increased industrial production - as a sign of genuine "recovery." 14 This view has been echoed by some of the politicians and general publics of the region, who place a lower value on the service economy and "speculation" than on goods manufacturing (as, indeed, do politicians and publics to some extent worldwide). On the other hand, an appreciation of the serious misallocation of resources produced by the socialist regimes' industrial drive suggests that the degree of decline in industry may also be taken as an indicator of the degree of success in restructuring Jackman and Pauna (1997). The need for sectoral reallocation of labor, with the inevitability of periods of search and waiting between jobs, has even led some observers to claim that the level of unemployment may provide a measure of the success of the transition overall McAuley (1991).

This paper has attempted to enable a better understanding of the nature of the industrial decline and its consequences in transitional economies. In doing so, the paper has shown that the decline of Romanian industry is not simple and uniform: although all sectors of industry appear to be affected by net employment declines, all have engaged in some hiring as well. Furthermore, sectors of industry exhibit significant heterogeneity in the size of their net outflows, and in the extent of turnover of their employment. Concerning the destination of workers who leave jobs from which they were employed in industry in 1993, I find a roughly even split between jobs in other industries and in services, on the one hand, and marginal activities in agriculture, unemployment, and nonparticipation in the labor force, on the other. The probability of these alternative destinations appears to be a function of a number of measurable determinants, including age, gender, rural/urban location, educational attainment, and ownership of 1993 employer, helping to identify the groups of workers who have been successful in moving to new jobs and those who represent some of the main social costs of the transition.

While the data set used in this paper has the distinct advantages of being large and representative, as well as based on a questionnaire designed according to internationally accepted concepts, it bears emphasis that I am unable to measure a number of important factors that would be useful for a better evaluation of the labor reallocation process. Future research, with this data set or with others, could investigate such issues as the impact of the incidence of part-time work, secondary jobs, and self-employment. It could examine the 1994 states and the transitions from 1993 to 1994 and from 1994 to 
1995. Particularly interesting might be an examination of workers who flow through unemployment in 1994. The specification could also be altered to take into account possible correlation of error terms over subsets of choices (e.g., by using a nested logit or multinomial probit framework). The sample and the set of issues could be expanded to include individuals older than working age and their retirement behavior - whether early or normal. Finally, other data sets would add useful information on such characteristics as wages and job quality, to permit better assessment of the degree to which labor market transitions are resulting in favorable outcomes.

\section{Endnotes}

${ }^{1}$ The matching procedure is also discussed in Voicu (2005), which is closely related to this paper.

${ }^{2}$ The survey did not follow respondents who changed address between March 1994 and March 1995, suggesting that the results below may understate the true degree of mobility (assuming that job mobility is positively correlated with geographic mobility). This problem is of course endemic to panel data sets, but as long as the characteristics of the two types of movers do not differ significantly, no bias induced will be induced in the findings reported below concerning the impact of determinants of changes in employment status.

${ }^{3}$ Although there were also a few cases of inconsistencies in reported educational achievement, they are not excluded based on the belief that the matching procedure eliminated any mismatches and thus that the inconsistency reflects reporting or coding errors. Moreover, educational achievement can change over time, and most inconsistencies involved implied increases rather than decreases in the amount of education.

${ }^{4}$ The results of pooling tests for different labor market states show that pooling the unemployed and nonparticipants into one group cannot be rejected in 1993 (when the state is defined on the basis of retrospective, self-identifying questions), but it can be rejected in 1994 and 1995.

${ }^{5}$ The analysis includes self-employed and employees in a single category of employed, leaving aside issues of the nature of self-employment in the restructuring employment; for such an analysis, see Earle and Sakova (2000). It should be noted, however, that most flows from industrial employment to agricultural employment represent employee-to-self-employment flows, as discussed further below. For more analysis of the ILO categories in Romanian LFS data, with comparisons to Estonia and Russia, see Brown et al. (2006).

${ }^{6}$ Andren et al. Andren et al. (2005) study the changing impact of education on earnings in Romania from 1950 to 2000. See also Earle and Pauna (1998).

${ }^{7}$ Earle and Oprescu (1995) contains a broader discussion of the labor developments in Romania's early transition, and in particular of the differences in the employment, wage, hours, and turnover behavior of industrial sectors over the period 1989 to 1993. Kotzeva and Pauna (2006) is a more recent study.

${ }^{8}$ See Commander and Tolstopiatenko (1997) and Jackman and Pauna (1997) for some analysis of the convergence of the structure of employment in East European countries to those of the West.

${ }^{9}$ The transition matrix differs from those in conventional analyses in market economies, which generally examine transitions only among three labor market states - 
employment, unemployment, and nonparticipation in the labor force - but ignore the issue of sectoral reallocation of labor, one of the critical processes of economic transition.

${ }^{10}$ After the rapid disbanding of agricultural cooperatives in the early 1990s, the Romanian agricultural sector became composed chiefly of very small farms.

${ }^{11}$ Unfortunately, the data do not permit me to observe individual job-changing within a sector, so this aspect of labor reallocation is not addressed in this paper. See Sorm and Terrell (2000) for such an analysis in the Czech Republic or Brown and Earle (2003) for Russia.

${ }^{12}$ This functional form can be justified as the outcome of a random utility maximization model, where $Y_{j}^{*}=U_{j}\left(X_{i}\right)+\varepsilon_{j}$, $U_{j}$ represents the systematic component and $\varepsilon_{j}$ the random component of utility, and the $\varepsilon_{j}$ are distributed independently and identically according to the type 1 extreme-value distribution. See Maddala (1983) for the derivation. The distinction between $\mathrm{X}$ and $\mathrm{Z}$ is made to facilitate the explanation of the simulations below.

${ }^{13}$ Unfortunately, the data do not permit the distinction between privatized and de novo firms.

${ }^{14}$ Blanchard (1997) and many of the papers in Holzmann et al. (1995); for a contrarian view, see Earle (1995).

Competing interests

The IZA Journal of Labor and Development is committed to the IZA Guiding Principles of Research Integrity. The author declares that he has observed these principles.

\section{Acknowledgements}

An earlier version of this paper appeared under the title "Industrial Decline and Labor Reallocation in Romania." I thank Sandu Voicu for valuable discussions, an anonymous referee for useful comments, and Tatiana Damjanovic for excellent assistance.

Responsible editor: Hartmut Lehmann

Received: 31 July 2012 Accepted: 23 August 2012

Published: 6 November 2012

References

Andren D, Earle JS, Sapatoru D (2005) The Wage Effects of Schooling under Socialism and in Transition: Evidence from Romania, 1950-2000. J Comp Econ 33(2):300-323

Blanchard O (1997) The Economics of Post-Communist Transition. Clarendon Press, Oxford

Brown D, Earle JS (2003) The Reallocation of Workers and Jobs in Russian Industry: New Evidence on Measures and Determinants. Econ Transit 11(2):221-252

Brown D, Earle JS, Gimpelson V, Kapeliushnikov R, Lehmann H, Telegdy A, Vantu I, Visan R, Voicu A (2006) Nonstandard Forms and Measures of Employment and Unemployment in Transition: A Comparative Study of Estonia, Romania, and Russia. Comp Econ Stud 48(3):435-457

Commander S, Tolstopiatenko A (1997) Unemployment, Restructuring, and the Pace of Transition. In: Zecchini S (ed) Lessons from the Economic Transition. Central and Eastern Europe in the 1990s. Kluwer Academic Publishers

Earle JS (1995) Interpreting the Decline of 'Output' and the Prospects for 'Recovery' in Eastern Europe. In: Gacs J, Holzmann R, Winckler G (eds) Output Decline in Eastern Europe - Prospects for Recovery? Academic Press, Kluwer

Earle JS, Oprescu G (1995) Romania. In: Commander S, Coricelli F (eds) Unemployment, Restructuring, and the Labor Market in Central Europe and Russia. World Bank-EDI, Washington

Earle JS, Pauna C (1998) Long-term unemployment social assistance and labor market policies in Romania. Empir Econ 23:203-235

Earle JS, Sakova Z (2000) Business start-ups or disguised unemployment? Evidence on the character of self-employment from transition economies. Labour Econ 7:575-601

Holzmann R, Gacs J, Winckler G (1995) Output Decline in Eastern Europe: Unavoidable, External Influence, or Homemade? Academic Publishers, Kluwer

Jackman R, Pauna C (1997) Labor Market Policy and the Reallocation of Labor Across Sectors. In: Zecchini S (ed) Lessons from the Economic Transition: Central and Eastern Europe in the 1990s. Academic Publishers, Kluwer

Kotzeva M, Pauna B (2006) Labour Market Dynamics and Characteristics in Bulgaria and Romania - Challenges for a Successful Integration in the European Union. Global Development Network, New Delhi

Maddala GS (1983) Limited-Dependent and Qualitative Variables in Econometrics. Cambridge University Press, Cambridge, Econometric Society Monographs 
McAuley A (1991) The Economic Transition in Eastern Europe: Employment, Income Distribution and the Social Safety Net, 4th edn. Review of Economic Policy, Oxford

National Commission for Statistics (1996) Romanian Statistical Yearbook., Bucharest

Sorm V, Terrell K (2000) Sectoral restructuring and labor mobility: A comparative look at the Czech Republic. J Comp Econ 28:431-455

Voicu A (2005) Employment Dynamics in the Romanian Labor Market: A Markov Chain Monte Carlo Approach. J Comp Econ 33(3):604-639

doi:10.1186/2193-9020-1-2

Cite this article as: Earle: Industrial decline and labor reallocation in a transforming economy: Romania in early transition. IZA Journal of Labor \& Development 2012 1:2.

Submit your manuscript to a SpringerOpen ${ }^{\circ}$ journal and benefit from:

- Convenient online submission

- Rigorous peer review

- Immediate publication on acceptance

- Open access: articles freely available online

- High visibility within the field

- Retaining the copyright to your article

Submit your next manuscript at $>$ springeropen.com 